\title{
The Holocaust in Romania:
}

\section{The Iasi Pogrom of}

\section{June I94 I}

\author{
RADUIOANID
}

\section{Background}

In 1930, the Romanian Jewish community, one of the largest in Europe, numbered 756,930 members. Of these, about I 50,000 lived in Northern Transylvania, which was occupied by Hungary in the summer of 1940 ; the remaining 600,000 Jews remained in territories ruled by Romania. In 1944, the Jews from Northern Transylvania shared the fate of the Hungarian Jews; only about I s,000 of them survived the deportations.

In 1923 a new Romanian constitution, adopted under the pressure of France, Great Britain and USA, had granted Romanian citizenship to almost all the ethnic minorities living in Romania. The rights granted to the Jews by the new constitution were challenged by the League of the National Christian Defence (later the National Christian Party) and by the Iron Guard, which, through a violent anti-semitic campaign, promised to implement 'numerus clausus' or 'numerus nullus'. In January and February 1938, King Carol II and Prime Minister Octavian Goga signed several decrees establishing 'the proclamation of the law of the blood' and the 'revision' of the granting of citizenship to the Jews. Soon afterwards the royal dictatorship of Carol II was established.

At the beginning of his dictatorship Carol II organised a severe repression against the Iron Guard. When, during the spring of 1940 , it became clear to him that Nazi influence would not be opposed soon in European Europe, Carol released the imprisoned Iron Guard members and included some of their leaders in the government. During the summer of I940, Romania was forced to give up Bessarabia and Northern Bukovina to the Soviet Union, Northern Translyvania to Hungary and two small districts, Caliacra and Durostor, to Bulgaria. One month before General Antonescu took power in alliance with the Iron Guard, the Gigurtu Government introduced severe anti-semitic legislation, openly inspired by the Nazi Nuremberg laws. This legislation remained in force after the fall of Carol and was further developed by the Antonescu-Sima and Antonescu governments.

The fate of the 600,000 Jews who remained under Romanian authority was determined by the changing attitudes of the fascist government; about so per cent of 
them were killed during World War II. At the beginning, the Jews of Bessarabia and Bukovina were either killed on the spot or deported to Transnistria (Soviet teritory under Romanian administration between the Dniester and the Bug), where massacres of the local Jewish population were already in progress. At least half the Jews deported to Transnistria had perished by 1944 .

In the Old Kingdom (Romania without Bessarabia, Northern Bukovina and Transylvania) anti-Jewish policies were somewhat less severe. Nevertheless, harsh discriminatory laws were imposed upon the Jews, and thousands of them were deported to Transnistria or to labour camps in Romania. Finally, massive pogroms (organised massacres of helpless people) took place in the Old Kingdom at Dorohoi, Bucharest and Iasi.

The Iasi pogrom is probably the best-known event in the history of the Romanian Holocaust. It was a major outbreak of violent anti-semitism, yet it was neither isolated nor fortuitous; rather it was part of a long series of mass murders committed by Romanian fascists. The Iasi pogrom was followed by the systematic deportation and extermination of the Jews from Bessarabia and Bukovina and by the extermination of the Ukrainian Jews from Transnistria. Even before the Iasi pogrom two cases of mass murders of the Jews had taken place in Romania. From 29 June to 6 July 1940, when Romanian troops were retreating from Bessarabia and Northern Bukovina, territories occupied by the Soviet Union as a consequence of the Ribbentrop-Molotov pact, at least I 36 Jews, of whom 99 have been identified, were murdered. Many Jewish travellers and soldiers were thrown from moving trains. It was in Dorohoi that the bloodiest episode occurred. A unit of the Romanian army executed at least fifty Jewish civilians, among whom were some old people and very young children.

During this time Romania was under the royal dictatorship of Carol II. When at the end of January 194I, the six-month-old alliance between the Iron Guard and General Antonescu broke down, I20 Jews were butchered in Bucharest by members of the Iron Guard. Thousands of Jews were beaten up and thousands of Jewish homes and businesses were destroyed. The Iron Guard was crushed and outlawed and General Antonescu survived as leader of the country. His administration nevertheless remained staffed with many supporters of the Iron Guard and with former members of the extreme anti-semitic National Christian Party.

According to Matatias Carp, the Iasi pogrom was the natural outcome of decades of Romanian anti-semitism:

The Government's official antisemitic policy was inaugurated in 1867 and was implemented for half a century with implacable perseverance. By as early as 1913 this policy had imposed on the nation 196 restrictive antisemitic laws... Then came the generation of 1922 , with its disastrous views and actions, the violence and beatings at universities, the ransacking of shops and the desecration of synagogues and cemeteries.... Murders went unpunished.... [Then followed] the Goga-Cuza Government, the rebirth of the Government's antisemitic policy, the pogroms of June 1940, Antonescu and the Iron Guard regime, with its own brand of plunder and crimes, discriminatory legislation that raised theft to the level of state dogma and, finally, the so-called rebellion, with the sorrow and desolation it left in its 
wake. All these are but stages on the endless road of persecution leading to extermination. ${ }^{1}$

Indeed, the road to extermination was paved by decades of incitement during which the anti-semitic extreme right Romanian newspapers systematically presented the Jews as the sole source of the economic and social problems which confronted Romania. Systematically the Jews were presented as racially inferior and degenerate, as parasites, a biological danger, the invaders of the Romanian state. Alcoholism, prostitution, liberalism, modernism, socialism, abortion and women's liberation were all blamed on the Jews. But besides the slander, beyond all the anti-semitic propaganda, plans for 'solving' the 'Jewish problem' were presented by the Romanian fascists. Inspired by the Nazis, in I938 Octavian Goga, the leader of the National Christian Party, proposed the deportation of all European Jews to Madagascar. ${ }^{2}$ Another Romanian fascist, Alexandru Razmerita, criticised the suggestion of a Romanian priest who wanted to drown all the Romanian Jews in the Black Sea as non-practical because of lack of ships. He proposed instead a 'total elimination plan' of the Jewish population. He wanted to deprive the Jews of the right to appeal against their deportation from urban to rural areas for forced labour. Razmerita proposed rural concentration camps, each with a 'capacity' of twentyfive to forty inmates. He also proposed forced labour for children over ten years of age whose identity cards were supposed to contain instead of their last names only the name of their 'owner'. ${ }^{3}$ Theorists of the Iron Guard proposed eugenics laws and practices including sterilistion of the Jews. ${ }^{4}$

Anti-semitism as a cause for pogroms was especially true of Iasi. There existed in that city a powerful and long-standing tradition of anti-semitism, already well entrenched by the nineteenth century. Iasi, the capital of Moldavia, had given birth to A. C. Cuza's League of National Christian Defence, a violently anti-semitic organisation, as well as to a dissident splinter, C. Z. Codreanu's Legions of the Archangel Michael. These hatreds escalated when Romania entered World War II in June I94 I. In the months preceding the beginning of hostilities against the Soviet Union, official Romanian anti-semitic propaganda increased. The Jews were subjected to stringent discriminatory measures and were consistently represented as an 'alien nation', 'Bolshevik agents' and a 'disruptive' and 'parasitic' element in Romanian society.

\section{Preparation of the Pogrom}

At the outbreak of war, Iasi, a city close to the Soviet frontier, had a population of

1 Matatias Carp, Cartea Neagra (thereafter, Carp, Cartea), 3 vols (Bucharest: SOCEC \& Co, I946-8), 2. II. Matatias Carp was the secretary of the Federation of Jewish Communities from Romania. He was given access to the folders of many Romanian war crimes trials. His 'Black Book' is a chronology of the Holocaust in Romania based on documents.

2 Octavian Goga, Paris Soir, Io Jan. 1938.

3 Aexandru Razmerita, Cum sa ne aparam de evrei-Un plan de eliminare totala (Turnu Severin: Minerva, 1938), 65-9.

4 Traian Herseni, 'Rasa si destin national', Cuvintul, 16 Jan. 1941, and Toma Petrescu, Ni se pierde neamul - Actiunea jidanilor impotriva natiei romanesti (Bucharest: Cugetarea, 1940), 124. 
slightly more than 100,000 inhabitants, approximately 50,000 of whom were Jews. Even before 22 June I94I a number of secret anti-semitic measures had been initiated in Romania. Thus, a few days before the outbreak of war, the Romanian director, General Ion Antonescu, sent an informal resolution to the Ministry of Propaganda demanding that 'all Judeo-Communist coffee shops in Moldavia be closed down, all kikes, Communist agents and sympathisers be identified by region ... Antonescu went on to emphasise: 'The Ministry of the Interior must know who they are, forbid them to travel, and be prepared to do with them whatever I shall order at the appropriate moment.' 5

On 2 I June I94I, the day before the German invasion of the Soviet Union, General Antonescu issued Ordinance No. 4I47, directing that all Jews between the ages of eighteen and sixty years who resided in the villages between the Siret and Prut rivers be evacuated to the Tirgu Jiu camp in the south of Romania; the first trains were to leave on 2 I June. Members of the families of those deported to Tirgu Jiu were evacuated to several towns. A time-limit of forty-eight hours was set for the execution of this operation. The order was counter-signed by Jack Popescu, Under-Secretary of State at the Ministry of the Interior, and was forwarded to the Supreme Headquarters of the Romanian Army, the Inspector General of the Gendarmerie, the General Directorate of Police and all prefectures. ${ }^{6}$ During his trial in 1946, Ion Antonescu explained it thus: 'It is a military principle that the population near the front must be displaced." He added that "the Germans asked us to put all the Jews from Moldavia in ghettos'.

Furthermore, a few days before the outbreak of war, at the meeting of gendarmerie units, General C.Z. Vasiliu, Inspector General of the Gendarmerie, had issued an order 'to clear the terrain', an order that entailed repressive measures against the Jews, including their deportion or liquidation. ${ }^{9}$ Some of the gendarmes who attended that meeting were in transit through Iasi during the pogram and also participated in the attack on the city's Jewish population. They did so while waiting to take up their posts in Bessarabia and Bukovina, where they also committed numerous crimes.

It is evident that the existence of a sizeable Jewish population in the immediate vicinity of the front line concerned both the Romanian and the German military authorities. In his post-war testimony, Lieutenant-Colonel Traian Borcescu, chief of the chancellory of the Special Information Service (Serviciul Special de Informatii, or SSI) during the war, declared: 'I know for certain that Section II of Supreme Headquarters was involved with the problem of moving the Jewish population in

5 Ibid, 2. 39, Order No. 62783 , signed by Gen. I. Steflea on I9 June I 94 I.

6 Documents Concerning the Fate of Romanian Jewry During the Holocaust (thereafter Documents), ed. Jean Ancel, 12 vols (New York: Beate Klarsfeld Foundation, 1986), 2. 468. Ancel is one of the leading authorities in the history of the Romanian Holocaust. Most of the documents originate from Israeli, Romanian and American archives.

7 Procesul marii tradari nationale (thereafter Procesul) (Bucharest: Eminescu, 1946), 53. Procesul is a collection of selected excerpts from the Antonescu trial.

8 Ibid., 64.

9 Documents, 6. 445. 
Moldavia under the auspices of the respective statistics offices, with Colonel Gheorghe Petrescu in charge of this activity. ${ }^{10}$ Section II of the Supreme Headquarters of the Romanian Army closely monitored the activities of political parties and ethnic minorities. It consisted of three bureaux of statistics, located in Bucharest, Iasi and Cluj, and collaborated intimately with the Special Information Service.

From historical documents accessible so far, it appears that the responsibility for the organisation of the Iasi pogrom rested with the Special Information Service, with Section II of Supreme Headquarters and with the German secret services, primarily the Abwehr. In his post-war testimony, Traian Borescu also stated:

As to the preparation and staging of the Iasi massacres, I suspect that they were the handiwork of the First Operative Echelon, since Eugen Cristescu [the chief of SSI] told me when he returned to Bucharest: 'The great deeds I accomplished in Moldavia, I accomplished in collaboration with Supreme Headquarters, Section II, namely with Colonel Radu Dinulescu and Lieutenant Colonel Gheorghe Petrescu.' I also know from [the SSI agent] Grigore Petrovici that Junius Lecca, Chief of the SSI network in Iasi, played an important part furnishing all the information on Jewish centres and congregations in Iasi. ${ }^{11}$

On the other hand, Eugen Cristescu, in his written post-war deposition, tried to deny the fact that the SSI was implicated in the Iasi pogram, maintaining that it was organised by the Gestapo, the SS Security Service (SD) and the Geheime Feldpolizei which, according to Cristescu, acted in Romania without the knowledge of the Romanian authorities (representatives of the SD and the Gestapo were indeed expelled from Romania because of their implication in the Iron Guard rebellion of January I94I).

Cristescu underscored the fact that the only secret service officially admitted to Romania was the Abwehr, whose liaison officer with the SSI was Major Hermann von Stransky. This German officer's name appears often in testimonies concerning the Iasi pogrom. Von Stransky, allegedly a nephew of the German Foreign Minister Joachim Ribbentrop, was married to a Romanian from Galati and spoke Romanian fluently, since he had lived in the country for many years. He worked closely with the SSI; for example, he informed the SSI of Horia Sima's unsuccessful attempts to cross the Romanian border illegally in January and February $194 \mathrm{I}^{12}$ It is possible that von Stransky was an agent not only of the Abwehr but also of other secret German services, though this has not been proved. Lieutenant-Colonel IonescuMicandru, head of SSI Section G (Germany), was the contact between von Stransky and the SSI.

Prior to the outbreak of war, to conform with others issued by the Prime Minister's Office and the Supreme Headquarters, the First Operative Echelon of the SSI was formed. Its official mission was to defend the front from sabotage, espionage and terrorism behind the lines. This echelon consisted of approximately I60 men.

12 Procesul, 170; Cartea, 2. 4 I. 
In June I94I the First Operative Echelon left for Moldavia. ${ }^{13}$ As to its mission, Traian Borcescu gave the following description:

One of the secret and unofficial aims of the expedition of this Operative Echelon was to do away with the Moldavian Jews by deportation or extermination. For this purpose, SSI department head Florin Becescu-Georgescu, when leaving Bucharest, took along the files on Jews and Communists. From Iasi, the Echelon drove to Kishinev, where Jews were massacred. The same SSI teams that operated in Iasi operated in Kishinev as well. The Echelon went also to Tighina and Tiraspol, where it committed robberies, and to Odessa, where it participated in massacres. ${ }^{14}$

Splinter groups of the First Operative Echelon robbed and assassinated people in other zones of Bessarabia and Transnistria. In Moldavia, for several days prior to the Iasi pogrom, members of the echelon were active in Roman, where they reported to the head of Section II of Supreme Headquarters, as well as in Piatra Neamt and Iasi and its environs.

German-Romanian military operations against the Soviet Union began on 22 June 194I. On the same day, thousands of Jews from rural areas in northern Moldavia were transported by train and interned in camps at Tirgu Jiu, Craiova, Caracal and Turnu Severin. Constantin Chirilovici, the Chestor (chief) of Police in Iasi, stated in a report that on the same date, 22 June, on Crucea Rosie Street, in front of No. 12, some twenty-five to thirty young members of the Iron Guard 'were instructed by two uniformed majors, a captain and a second lieutenant'. ${ }^{15}$

The first air-raid on Iasi by the Soviet Air Force took place on 24 June and hit the Ripa Galbena area and the railway station. It caused minor damage and left a few victims. The air raid produced anti-Jewish hysteria. Military personnel, the Iron Guard and members of the League of National Christian Defence spread the rumour that the entire Jewish population of Iasi was in the service of the Red Army and had provided ground signals for the Soviet Air Force. 'On 25 June, Iasi policemen scoured houses asking the gentile population to put the sign of the cross on their windows and over entrances. ${ }^{16}$ A similar phenomenon had occurred one year earlier during the Dorohoi pogrom.

On 26 June at I I:00 am, the second Soviet bombing of Iasi took place. This time the results were devastating. The headquarters of the Fourteenth Division, the central telephone office and Saint Spiridon Hospital were hit; 60o people died, of whom 38 were Jews. According to other sources, there were I I I dead and hundreds

13 Ibid., 2. 19.

14 Ibid., 2. SI-2.

15 Aurel Karetki and Maria Covaci, Zile insingerate la Iasi (thereafter Karetki and Covaci, Zile) (Bucharest: Editura Politica, 1978), so, citing Arhiva Ministerului Apararii Nationale, fund IV Army, dossier 6262/1941, 195-200. Zile insingerate la lasi is a revisionist book and the only one published between 1948 and 1989 which dealt extensively with the Holocaust in Romania. The Iron Guard was the Romanian fascist party; it was suppressed by Antonescu in January I94I. One of the majors was Gheorghe Balotescu, SSI chief in Iasi, and the other was probably Emil Tulbure, also a member of the SSI network in Iasi.

16 Documents, 6. 35, Braunstein testimony on the Iasi pogrom; Carp, Cartea, 2. 61, testimony of Colonel N. Lupu, commander of the Iasi garrison. 
of wounded. ${ }^{17}$ As a result of this bombing, anti-Jewish hysteria increased. Romanian military reports mentioned finding some lasi Jews among the crews of the shot-down Soviet airplanes. There was also talk of the presence in town of some Soviet saboteur paratroopers.

At that time the Romanian units in Iasi consisted of soldiers of the Fourteenth Division, a company of the Thirteenth Regiment of 100 men, and 300 men from the battalion of gendarmes. ${ }^{18}$ There were also 450 local policemen and 330 policemen from around the country who were eventually to take up their posts in Bessarabia and Bukovina. Also present were German troops from the Thirtieth Army Corps, the 198th Division, as well as SS troops and members of the Todt organisation. ${ }^{19}$

On 20 June Hery Staerman (of 7 Ipsilante Street), leader of a forced labour camp of 1 Io young Jews, received an order from the Paramilitary Preparation Inspectorate of lasi to go to the Pacurari Jewish Cemetery hurriedly to dig two graves of the sizes indicated by the Town Hall technical department. The graves were ready on $26 \mathrm{June}^{20}$

In his testimony one of the survivors named Braunstein described the graves as being either 30 or I 5 metres in length, two metres wide and two metres deep. He also made clear that the order to dig the graves was issued two weeks before the pogrom. ${ }^{21}$

Also on 26 June I941, Major von Stransky and SSI Colonel Ionescu Micandru arrived at the headquarters of the Fourteenth Division, where they remained several hours before leaving for Holboca. ${ }^{22}$ After the war Lieutenant-Colonel Constantin M. Radulescu Sita of SSI stated that on the occasion of Eugen Cristescu's birthday, 24 December 1942, he was at a table at SSI headquarters in Bucharest and overheard Ionescu Micandru tell von Stransky: 'Don't worry, we will put an end to the Jewish problem [in Bucharest] just as we did in Iasi; when some of us got tired, others took our place. Isn't that so, Sandu?'23

Thursday, 26 June, was also significant because on that day the Iasi pogrom claimed its first victims. The Thirteenth Dorobanti Regiment, in its report to the Fourteenth Division, stated that Iosub Cojocaru, Leon Schachter and Herscu Wolf, residing at 27b Vasile Lupu Street, signalled with rockets to the Soviet Air Force the location of buildings occupied by the Romanian Army. Escorted under guard to the headquarters first of the regiment and then of the division, the accused were searched by two Romanian officers, who set them free. Since the Copou hill, where the divisional headquarters was located, was a restricted area to Jews, the three

17 Ibid., 2. 22, 95; Karetki and Covaci, Zile, 45, citing Arhiva Ministerului Apararii Nationale (AMAN), fund 'Comandament IV teritorial', dossier I 349/1941, 232.

18 Ibid., 45-6 citing Archiva Ministerului Afacerilor Interne (AMAI), 29. 9-10.

19 Ibid.

20 Marius Mircu, Pogromul de la Iasi (thereafter Mircu Pogramul) (Bucharest: Glob, I945), s.

21 Documents, 6. 43.

22 Ibid., 6. 376-7; and Carp, Cartea, 2. 58.

23 Documents, 6. 377; and Carp, Cartea, 2. 53. The person referred to as 'Sandu' was Major von Stransky. 
prisoners were escorted by Sergeant Mircea Manoliu, a member of the Iron Guard; he took them to the garrison's target practice range, where he shot them. Schachter managed to escape; Herscu Wolf, though badly wounded, fainted but survived; Cojocaru died. ${ }^{24}$

On the same day, five unidentified Jews were sent to mark with lime the location of unexploded bombs in the courtyard of the headquarters of the Thirteenth Dorobanti Regiment. Although they had been instructed to perform this task by Police Inspector Nicolae Craciun, the five Jews were accused of espionage and detained at regimental headquarters. ${ }^{25}$

On the afternoon of 26 June, the leaders of the Jewish community of Iasi were ordered to present themselves at the Chestura, the central headquarters of the Iasi police, where they were told that the Jews of Iasi were guilty of collaborating with 'downed Jewish Soviet pilots'. The Chestor of Iasi, Lieutenant-Colonel Chirilovici, ordered that all binoculars, flashlights and cameras be handed in within 48 hours. ${ }^{26}$ At $4.00 \mathrm{pm}$ the following officials gathered at the headquarters of the Iasi prefecture: the county prefect, Colonel Dumitru Captaru; the garrison commander, Colonel Constantin Lupu; the Chestor, Lieutenant-Colonel Constantin Chirilovici; Security Inspectors Giosanu and Cosma; the Chief Public Prosecutor; and the municipal physician. They decided to add a detachment of gendarmes to each police station and ordered house-to-house searches to catch saboteurs and spies. ${ }^{27}$ As a result, that very evening between the hours of 5.00 and 9.00 , many Jewish homes were raided and searched. Forty teams composed of 140 policemen and 677 gendarmes, all of them Romanian, participated in this operation: 317 Jews were picked up and taken to the Chestura; of these, 207 were detained because they owned flashlights or objects made of red cloth. ${ }^{28}$

On Friday, 27 June I94 I, isolated shots were heard, and immediately after I I am, Colonel Lupu, the garrison commander, telephoned Chestor Constantin Chirilovici, and told him:

I was informed that a group of Iron Guards have gathered in a pavilion in the Pacurari district Jewish Cemetery [near the graves that had been dug earlier]. They were singing legionnaire songs and alarming the population. I immediately ordered a platoon of soldiers into trucks, and we drove to the scene of the disturbance where I found some 30 or 40 Iron Guards, all of them armed. By the time we arrived, they were beginning to disperse. In the pavilion where they had gathered I found two cases of weapons. Two of them approached me and told me that they had been sent by Supreme Headquarters and the SSI to arm the Iron Guards, who were then supposed to infiltrate behind the enemy front. I asked these two why they had not reported this plan to us too, then I withdrew my troops to military quarters. Approximately one hour later, the two persons with whom I had spoken earlier, presented themselves to me dressed in majors' uniforms and asked my forgiveness, saying that they had tried to implement a secret plan of operation, but that it had not come off. I file 95 .

Ibid., 2. 22-3, and Documents, 6. 368.

Ibid., 6. 369.

Carp, Cartea, 2. 66.

Ibid., 2. 25, 6I; Documents, 6. 369.

Karetki and Covaci, Zile, 57, citing AMAN, fund 'I 4 th Infantry Division', dossier I17, 
searched these two officers, who showed me their orders from Supreme Headquarters. I reported this case to the commander of the Third Army. ${ }^{29}$

The two majors were SSI officers Gheorghe Balotescu and Emil Tulbure, who had organised a similar operation in Iasi on 22 June $194 \mathrm{I}$, but at that time they had been in uniform. The explanation they gave, that they intended to place Iron Guards behind enemy lines, was somewhat curious to say the least, in view of the extremely noisy manner in which these so-called 'agents' were being prepared for duty. Also curious was the behaviour of Colonel Lupu, who allowed armed Iron Guards, at that time considered a danger to the security of the country, to disperse, although he was accompanied by at least two truckloads of soldiers.

On the evening of 27 June in the Nicolina district, Dr Marcu Kaufman's father was fatally shot in the back by an artillery sergeant, a member of a Romanian unit. ${ }^{30}$ That same evening five Jewish men, detained at the Thirteenth Dorobanti Regiment and accused of espionage, were entrusted to the same Mircea Manoliu, to be escorted for interrogation to the headquarters of the Fourteenth Division. Instead of taking them to their destination as ordered, Mircea Manoliu, accompanied by Corporal Nicolau (or Nicolae), stopped at the target range where they shot all five, something that Manoliu had done there to other Jews earlier. The five corpses were found the following day, and the county prefect reported the incident to the commander of the Fourteenth Division, mentioning not five but six victims. ${ }^{31}$

\section{The Pogrom Unfolds}

A combination of long-time anti-semitic traditions, terror spread by the military operations, official anti-semitic propaganda and the manipulations organised by SSI made the Jewish population of Iasi an easy target for the pogromists. On the morning of Saturday, 28 June I94I, a group of thirty soldiers from the Thirteenth Dorobanti Regiment and from Artillery Regiment 24, led by Sergeant Mircea Manoliu, robbed and abused several Jews on the pretext that they were searching for a radio transmitting station. That same morning German soldiers also participated for the first time during the Iasi pogrom in the mistreatment of Jews. Incidents occurred in the Tatarasi District on Rachiti Street and in the Abator (slaughterhouse) District on Aurel Vlaicu and Vasile Lupu streets. The Chestor arrived at the scene, as did the garrison commander, the Chief Public Prosecutor of Iasi, the Pretor of the Fourteenth Division and a platoon of gendarmes. Mircea Manoliu was arrested but shortly thereafter released by the Pretor of the Fourteenth Division, Major Nicolae Scriban. ${ }^{32}$

At the same time, printed posters began to appear on walls in Iasi openly calling for the massacre of Jews: 'On Saturday, 28 June, I saw posters glued to the walls of houses, calling for a pogrom. For instance: "Romanians! Each kike killed is a dead

29 Carp, Cartea, 2. 25, 61; Documents, 6. 369.

30 Mircu, Pogromul, 9.

31 Documents, 6. 369, 2. 433; Carp, Cartea, 2. $25,69$.

32 Documents, 6. 369-70, 2. 433; Carp, Cartea, 2. 26. 
Communist. The time for revenge is now!" 33 Members of the civilian population then joined those in uniform. Moreover, on the evening of 28 June, Police Commander Gheorghe Leahu ordered Iasi policemen 'not to get involved in whatever the army may do in town, whether good or evil'. ${ }^{34}$

At $9.00 \mathrm{pm}$ on 28 June, an aeroplane, probably German, fired a signal rocket; accounts differ as to whether it was blue or red. Immediately afterwards, volleys of diverse calibres of firearms were heard throughout the city. They created a high state of panic among the ranks of the military who at the time were passing through Iasi on their way to the front. There was shooting in the districts of Pacurari, Toma Cosma and Sararie, as well as in Carol, Lascar, Catargiu and Lapusneanu streets. The military units passing through the city fanned out in fighting positions and returned the fire.$^{35}$ In his report to Ion Antonescu, dated 2 July 1941, General Leoveanu, the Director General of Police entrusted with the inquiry into the lasi events, stated that no dead or wounded were found among either German or Romanian troops. What they did find, however, were shells from duelling pistols. ${ }^{36}$

A rumour spread that Soviet paratroopers were active throughout the city. As a result, throughout the night groups of soldiers, gendarmes and army recruits, Romanian as well as German, accompanied by civilians, plundered and murdered Jews:

On the night of 28 June I94I, a group of young gentiles led by the coachman Lepioskin, and accompanied by soldiers, went into the outskirts of the Abator neighbourhood and began plundering and killing. Also that night, an air-raid alarm sounded at $9.00 \mathrm{pm}$ and lasted until 8.00 am next day. A group of soldiers and paramilitary entered the building at 3 Stefan cel Mare Street, where they shot and killed Iosif Smilovici, owner of the knitwear store Minca. Another group entered the courtyard of the Binder Hotel in Lapusneanu Street and, with the pretext that they had found a machine-gun in the attic, arrested Blau, the manager of the hotel, his wife, his daughter, a sister-in-law, and his mother-in-law. After a summary trial, they were executed: machine-gunned in front of the building of the Ferdinand Foundation. Blau was a cinematographer, well known as a man of peace, incapable of committing a crime. The truth, as it was later learned, was that the machine-gun had been placed in the hotel attic by some Iron Guard soldiers who were guarding Tax Collection Office No. I, located in the same building. In fact, these soldiers had robbed Blau earlier in the evening. ${ }^{37}$

A report sent at 9.30 am on 29 June from the regional police to police headquarters in Bucharest demonstrates the attitude of the Romanian authorities:

In Iasi, on the night of 28-29, at $10.30 \mathrm{pm}$, Communist Jews and a few Romanian Communists opened heavy machine-gun fire. Their aim was twofold: to provoke panic among the population and to stop the movement of marching troops. The police, the Romanian and German armies, were immediately alerted and proceeded to search houses. ${ }^{38}$

33 Ibid., 2. 89, statement of the witness Israel Schreier; Documents, 6. 370, indictment in the trial of war criminals, dossier $5266 / 1947$.

34 Carp, Cartea, 2. 26, 67.

35 Ibid., 2. 26.

36 Ibid., 2. 116.

37 Documents, 6. 35, Braunstein testimony.

38 Carp, Cartea, 2. 83, Report No. 23469 from regional Police Inspector E. Giosanu. 
A report of 29 June from the Iasi regional police to police headquarters in Bucharest specified that shortly after $10.00 \mathrm{pm}$ on 28 June, Colonel N. Lupu, Garrison Commander, Colonel Barozi, Pretor of the Third Army, Colonel Gheorghe Badescu, Inspector of the Gendarmes, Major Scriban, Pretor of the Fourteenth Division, and Police Inspector E. Giosanu arrived at the Chestura to evaluate the situation and sent their report to the commander of the Fourteenth Division. Additional police were immediately sent to reinforce the gendarmes and the public guards (the urban patrols) who had been dispatched to the scenes of disturbance earlier in the day. ${ }^{39}$ At this meeting it was decided that 'suspects' would be rounded up the following day and taken to the Chestura.

On the morning of 29 June, a Sunday, shots were heard again. This time, Jews were direct targets. The surviving Jews were formed into columns and marched from Tatarasi, Pacurari, Sararie and Nicolina streets to the Chestura. Some columns made temporary stops at the National High School, the headquarters of the Thirteenth Dorobanti Regiment, the Wachtel School or the Regional Inspectorate of Security, but the ultimate destination was nevertheless the Chestura. Most of the prisoners were men, but among them were also some women with children. Some were dressed; others were in their nightclothes. Many had been beaten and had bruises and open wounds. Most of them were forced to march in step with their arms raised. Civilian onlookers, as well as soldiers and gendarmes, Romanian and German, spat at them and hit them with stones and broken pieces of glass, clubs, crowbars and rifle butts. Prisoners unable to walk because of the blows they had suffered or because of physical disabilities were shot, so that the streets were strewn with corpses. ${ }^{40}$

In the Pacurari section, Dr Piker was shot in front of his wife. Also murdered were the following manufacturers: Fall, his son and his son-in-law; Holzman and his only son, a high school student; Schneer with two sons; and the engineer Pulferman and his son-in-law. In the Bratianu section, the shopkeeper Milu Goodner was killed in front of his wife; also killed were $\mathrm{Dr} \mathrm{H}$. Solomonovici, who was visiting his daughter on Bratianu Street, and Dr Manole Solomon. On Stefan cel Mare Street, an eight-year-old girl, Tauba Grunberg, was shot. She was found disembowelled in front of the Hirschenson store. On the same street, at the corner of Lozonski Street, the family of the publican Samuel Leibovici was gunned down. The father, daughter and son died instantly; the mother, fatally wounded, died at the Ghelerte Hospital. The hotel-owner Herman Rotman was found shot on University Street.

Plunder was the motive for some of these attacks. The actor Vinovschi, an accomplice in the murder of the Leibovici family, immediately took over their property. ${ }^{41}$ At 2 Xenopol Street, the merchant Jean Olivembaum and the Marcusohn family of three were shot and killed. German soldiers propped up Olivembaum's corpse on a machine-gun emplacmeent and took a picture. This photograph, published in the German magazine Der Adler, was supposed to prove that

39 Ibid., 2. 70, 108; Documents, 6. 370 Report No. 23621.

40 Carp, Cartea, 2. 27-8; Documents, 6. 371.

4 Documents, 6. 36-7, 384, Braunstein testimony; Mircu, Progomul, 3 I-3. 
Jews were shooting at the German army. The lawyer Altein met with the same fate. On Stroescu Street, at the corner of Vovidenie Street, some German soldiers asked people in a shelter whether there were any Jews among them. When told that there were none, they left; but a baptised Jew, the lawyer Cecilia Reiter, denounced the paediatrician Cozac Averbuch. The Germans returned to the shelter and shot him. Moscovici, who was eighty years old, was shot at 20 Saint Andrei Street by Romanian soldiers. At the same time, his son was shot on Saint Lazar Street. ${ }^{42}$

Often, when Jews were led off to the Chestura, they were robbed:

The baker Herscu Marcu (27 Zugravi Street) was picked up early in the morning by a Gypsy from the slums armed with a club. The Jew took his wife and two children with him. He was not allowed to lock up his house. In his absence he was robbed of all his possessions. Avram Ihil, a 24-year-old office clerk, and his family were dragged out of their home and badly beaten. Racovita, a medical examiner at the Saint Spiridon Hospital morgue, assaulted Ihil's father. His mother was dragged into the street by her hair. All three were taken to the Chestura. In their absence, their house was plundered of everything. Colonel Mihail Niculescu-Coca was billeted in Solomon Sternberg's house (24 Pacurari Street). While Sternberg and his family were being transported to the Chestura, the colonel's orderly stole as much as he could. When the Sternbergs returned home, they complained to the colonel that they had been beaten. The colonel, their guest, slammed the door in their faces. ${ }^{43}$

Civilians frequently joined the police and the military in dragging Jews out of their homes. For instance, a group of Jews, among them Hery Staerman of 7 Ipsilante Street, 'were taken from their homes by several Romanian railway employees, who lived in the same neighbourhood. They had the same calibre of guns as the guards whom they accompanied.'44 Some Jews were killed on the spot:

Leon Davidovici (8 Pinzaritei Street) and his father were taken out of their home by Roman, a member of the public guards, husband of the cashier of the Trianon, who lived across the street. The guard was accompanied by a German officer. At the gates of their house, the father was hit on the head with a crowbar. Within seconds he was dead in his son's arms. ${ }^{45}$

Many more eyewitness accounts of the assassination of Jews in the streets of Iasi were collected by the Bucharest prosecutor. The notorious Iron Guard Stefan Scobai fatally shot Itic Burstin and Mihail Herman on Bratianu Street. Dumitru Cercel, a policeman attached to the sixth precinct of the Iasi police, killed four Jews; Dumitru Constantinescu, a follower of Cuza, bludgeoned to death several Jews; and public guard Gheorghe Grossu murdered one Jew. Other killers, whose victims died immediately or shortly thereafter from severe beatings or stab wounds, included the wood sculptor Stefan Scobai; the public guards Leon Cristiniuc, Constantin Blindut, Rudolf Lubas, Mihai Antitulesei and Ion Ciubotaru; the merchant Dumitru Dadirlat and the clerk Nicolae Russu; the Iron Guards Dumitru Andronic, Ioan Laur and Dumitru Dumitriu; the pedlar Vasile Velescu; the student Aurel Gramatiuc; and several other civilians named Gheorghe Tanase, Nicolae

44 Ibid., 20.

45 Ibid. 
Lupu, Ion Manastireanu, Ion Bocancea, Gheorghe Grossu and Dumitru Ciubotaru. ${ }^{46}$

During their forced marches to the Chestura, the columns of Jews often came upon corpses. Thus a column that left the Fifth Police Precinct at $5.00 \mathrm{pm}$ under an escort led by the public guard Angelescu saw the corpse of an old man on Apeduct Street. A little further they came across the body of a child, offspring of the tinker Suchar. On Cuza Voda Street, by the Chamber of Commerce and in front of the store Ghemul Verde, the prisoners saw two piles of corpses, among them women and children. On Vasile Alecsandri Street, a German soldier shot an old man in the back of the head. The bodies of Smil Idelovici and Moise Leb, father-in-law and son-in-law, lay by the entrance to the Chestura.

Another group of Jews formed a column on Smirdan Street and were led away by soldiers and public guards. On their way they saw the body of an old Jew who had pinned to him a note from the Chestura stating that he was free; a German soldier had shot him. In Sirota Grossu's dental office, the publican Schneider, a boy, an old man and several others were found on the floor, shot dead. More corpses of Jews were stacked in front of the Jelea pharmacy, at the corner of Sararie. ${ }^{47}$

On occasion gentiles did come to the rescue of Jews. Isodor Sulemer was caught in a roundup at 42 Stefan cel Mare Street. Two Romanian officers happened to be passing by and forced the escorts to free the Jews. ${ }^{48}$ Sometimes Jews escaped the forced march to the Chestura by purchasing the goodwill of the men involved in the raid. For example, several Romanian military men and a few civilian slum-dwellers entered Mendel Sacagiu's home at 55 Smirdan Street. They left after the military men each received $\mathrm{I}, 000$ lei and the civilians so lei. ${ }^{49}$

The outcome of these encounters was, however, not always so favourable. On the same Smirdan Street, the mob was led by shoe-makers Ioan Munteanu, Cucu and Turila, all living on the same street. The first two carried sticks and Turila was armed with a shovel. They rounded up some eighteen Jews, among them Herscu Waldman. The civilians snarled: 'To the slaughterhouse.... You shot eleven Germans. Just you wait, we'll show you.' They forced the Jews to walk with their arms above their heads and hit with bayonets those who did not keep their arms high enough. They marched for some three kilometres, from Smirdan Street to Vasile Lupu, Oancea and Abator streets, as far as the Aviatia. On the way neighbours spat at them and hit them, saying: 'Look, they caught last night's bandits. They're all Jews, didn't I tell you?' When they reached the Aviatia field, the mob opened fire with machine-guns. Eleven were killed and the rest fled to the Eternitatea cemetery. They were not pursued. 50

Other massacres were avoided at the last moment. Thus a convoy of 800 to $\mathrm{I}, \infty 00$

4 Documents, 6. 364-419, Office of the Prosecutor, Bucharest, War Criminals Section, Dossier No. $5260 / 1947$, esp. $384-5,387-8,390,392-8$.

47 Ibid., 6. 20-2, 24.

48 Ibid., 6. 28-9.

49 Ibid., 6. 24.

so Ibid., 6. 19. 
Jews, including women and children, among them the carpenter Iosub Weissman (I42 Socola Street), David Itic Meier (s Calusei Street) and the civil servant Itic Moritz (I 3 Socola Street), were made to lie face down on the banks of the Bahlui River beside several large pits. They were beaten by railway employees Petru Gadea and Cassian Cazacu; the carter Costache Panaite; Costica Damian; and Petrescu, a maker of brandy stills. One of the prisoners, a rabbi from Buhusi, was drowned. The chauffeur of Chestor Chirilovici witnessed the scene and alerted his boss. Chirilovici arrived immediately on the scene, accompanied by another officer. He saw a sergeant about to fire his machine-gun at the Jews and ordered him to free them. ${ }^{51}$

Sometimes, those who attempted to defend Jews were killed with them. This was the case with engineer Naum, a gentile, brother-in-law of Chief Public Prosecutor Casian. Naum, a former Assistant Professor of Medical Chemistry at the Iasi Institute of Hygiene, well known in select circles as an eloquent defender of liberal views, attempted to save a Jew on Pacurari Street, outside the Ferdinand Foundation. The Romanian officer who was about to kill the Jew said to Naum, 'You dog, die with the kike you are defending', and shot him point-blank. The priest Razmerita was shot on Sararie Street while attempting to save several Jews, dying with the victims he tried to protect. While trying to defend some Jews on Zugravilor Street, outside Rampa, the lathe operator Ioan Gheorghiu was killed by railway workers. ${ }^{52}$

Some potential tragedies were, however, averted. For instance, although a band of Romanian soldiers threatened to shoot him, Grigore Porfir, manager of the Dacia mill, was able to rescue about Ioo Jewish workers who were inside the mill.53 Similarly, the pharmacist Beceanu risked his own life to save dozens of Jews. ${ }^{54}$ Police Inspector Suvei freed 350 Jews who had been rounded up and whom he was supposed to escort to the Chestura. Police Inspector Mircescu and the public guard Sava saved many Jews either by advising them to stay indoors or by keeping them under arrest but not sending them to the Chestura. ${ }^{55}$

Thousands of Jews were herded into the courtyard of the Iasi Chestura. A report provided details:

So far, I,, 00 people have been arrested, almost all Jews. By order of the General Commander, this procedure will be repeated daily. We do not have details, as the operation is in progress. These operations are conducted under the supervision of the Chief Army Pretor, of the Inspector of Gendarmes, and of the Deputy Chestor of the Iasi Police, Lieutenant-Colonel Chirilovici. ${ }^{56}$

Another report, signed by Lieutenant-Colonel Chirilovici and addressed to the Iasi Inspectorate of Police and Security, stated that about I,800 women, children, and men were held in the Chestura courtyard at $9.00 \mathrm{am} .{ }^{57}$ In a report to the Ministry of

53 Minimum, no. I 8, (Tel Aviv, 1988): 78, testimony of Leizer Ghidale.

54 Moses Rosen, 'Uitare? Iertare? Reabilitare?', Revista Cultului Mozaic (Bucharest, is Oct. 1986):

4

55 Karetki and Covaci, Zile, 80, citing AMAI, Dossier 108233, Vol. I, pt 2, 457; Carp, Cartea, 2. 66 , testimony of Iacob Nahumovici.

56 Ibid., 2. 83, Report No. 23469 , telephoned 29 June 1940, 9.30 am.

57 Ibid., 2. 8s. 
the Interior, the county prefect, Colonel Dumitru Captaru, stated that by $1.00 \mathrm{pm}$ there were 'about 3,500 suspects, most of them Jews', in the Chestura courtyard. ${ }^{58}$ In yet another report, addressed to the Minister of the Interior, Lieutenant-Colonel Chirilovici accounted for 1,000 Jewish prisoners at 9.00 am and 5,000 at nightfall ${ }^{59}$ The Chestor stated that at noon there were 3,500 Jews in the Chestura courtyard. ${ }^{60}$ General Stavrescu, commander of the Fourteenth Division, made several appearances in the Chestura courtyard.

At I I.00 am, after Stavrescu left, a committee consisting of Police Inspectors Dumitru Iancu and Titus Rahoveanu performed a selection among the prisoners. Some were set free because their identity cards were in order or as a gesture of goodwill. They freed women, children and doctors. All of those released received slips of paper with the inscription free and the stamp of the prefecture. Some of those freed were, however, shot in the street as they walked back to their homes. Others were brought back to the Chestura after a few hours despite their stamped pieces of paper. The number of those released varied between 200 and 2,000, depending on the source of information. While some Jews were leaving the Chestura, more columns continued to arrive. Many Jews went there on their own initiative in order to get a note stamped free.

At about noon SS soldiers and members of the Todt organisation formed a living corridor through which columns of Jews had to pass in order to enter the Chestura courtyard. The Germans were joined by Romanian gendarmes, policemen and civilians, among them Gheorghe Bocancea and Ghita Iosub. ${ }^{61}$ Armed with iron crowbars and wooden cudgels, they beat their victims, usually hitting them on the head. Among those killed in this manner were Lucian Berman, Iancu Soicat (22 Mirzescu Street), his nineteen-year-old son Sami and the boy's seventyfive-year-old grandfather, Haim Segal. ${ }^{62}$

At about I.30 pm, German soldiers and Romanian gendarmes and soldiers surrounded the Chestura and an area close by, including Vasile Alecsandri, Cuza Voca and Bratianu streets, and Piata Unirii. According to some witnesses, the Romanian authorities lost control of the situation. At about $2.00 \mathrm{pm}$, the German and Romanian soldiers and policemen began to fire directly into the crowd; they were joined by some civilians, among them Dumitru Dumitriu, who owned a machine workshop near the Chestura. ${ }^{63}$ They used machine-guns, automatic weapons or rifles. Crazed with terror, some Jews tore down the fence of the Chestura and tried to take refuge near the Sidoli Cinema and in the surrounding streets and houses. These, too, were mown down without mercy. In addition, the killers stripped the corpses of watches and fountain pens. It was an apocalyptic scene: 
I saw a multitude of people rushing in confusion towards the Zafiropol garage, near the Chestura, in a hail of machine-gun fire. Two bullets grazed me as I fell to the pavement. I lay in this state for several hours, and saw with my own eyes people die in front of me, some of whom I knew, others who were strangers. For instance a wounded Jewish veteran of the 1916-I918 campaign, with his medals for 'Courage and Faith' still pinned to him, in his hands papers that entitled him to rights (as a Romanian citizen), his chest torn open by bullets, died like a dog in a rubbish tip. Then there was young Segal, son of a leather dresser (who also died, together with his two other sons), who kept moaning as he was dying: 'Mother, father, where are you? Give me water, I'm thirsty.' But nobody could help him. The soldiers passing by saw Jews in their agony and pierced them with their bayonets to end their misery. ${ }^{64}$

The massacre continued intermittently until $6.00 \mathrm{pm}$, with a pause for General Stavrescu's return at 4.30 .

It is very difficult to establish the number of victims of the Chestura massacre. According to two sources, there were approximately I,000 victims. In his statement, Georghe Leahu, also a Chestor of Iasi, declared that when the massacre began there were 3,500 Jews in the Chestura courtyard and that after the massacre some 2,500 Jews were lined up in columns and led to the railway station. ${ }^{65}$ Marius Mircu makes reference to 900 dead ( 500 in the Chestura courtyard and another 400 at the Sidoli cinema). ${ }^{66}$ Two hundred and fifty-four bodies were buried in communal graves in the Jewish cemetery. Four trucks and twenty-four carts transported the corpses. It took two whole days to move them. Some corpses were dropped off at the Copou district garbage dump. They had been stripped. Many wounded and dying were buried with the corpses, having been stacked in piles before being carted away.$^{67}$ Even an official communiqué issued to the press later acknowledged that 500 Jews died, and went on to explain:

The Soviets are trying in every possible way to inspire sabotage, disorder and aggression behind the front. To this end they parachute spies and terrorists from airplanes. Once on land, the enemies contact local agents in Romania and Judeo-Communists, organising jointly acts of aggression. Some agents have been caught and punished for attempted acts of aggression. In Iasi, soo Judeo-Communists, who had shot from houses at German and Romanian soldiers, were executed. All further attempts to disturb peace and order will be mercilessly repressed. ${ }^{68}$

It may seem that the only part played by the SSI was to prepare the Iasi massacre. This is, however, untrue, as can be seen in several testimonies, especially the evidence of Colonel Traian Borcescu:

With regard to the massacre: First Operative Echelon was not instructed to kill, but teams were formed by members of the Echelon and did take part in the butchery. A team was led by Grigore Petrovici and Captain Gheorghe Balotescu, another by Major Tulbure, another

66 Mircu, Pogromul, 43.

67 Carp, Cartea, 2. 144; Mircu, Pogrumul, 45.

68 Universul (Bucharest), 2 July I94I. 
by Gheorghe Cristescu Gica, Eugen Cristescu's brother. These teams were under the command of Director Florin Becescu-Georegescu. ${ }^{69}$

During the afternoon of 29 June, the decision was reached to evacuate from Iasi those Jews who had been detained as suspects at the Chestura. According to Chestor Chirilovici, the order was issued by General Stavrescu, commander of the Fourteenth Division, and by the county prefecture. ${ }^{70}$ The decision was probably made following a meeting that took place on Sunday afternoon, 29 June. The participants were General Stavrescu, a high-ranking German officer, Chestor Chirilovici and Chestor Leahu, Chestura Director Stanciulescu, Commissar Anghel and Major Scriban. ${ }^{71}$ Approval for the evacuation was sought from the Ministry of the Interior, which granted it over the phone. ${ }^{72}$ The county prefect also spoke on the telephone to Mihai Antonescu, who instructed him to stay in contact with the Ministry of the Interior, which was to evacuate the 'suspects'. ${ }^{73}$

Approximately 2,500 Jews survived the massacre in the Chestura courtyard. Their transportation to the railway station began at $8.00 \mathrm{pm}$. In charge of this operation were one police inspector, two police officers, two police section chiefs and twenty public guards. The convoy was also escorted by German officers, soldiers in two armoured cars and several motorcyclists. ${ }^{74}$ When they reached the railway station, the prisoners were made to lie face down while being counted, a procedure that took a long time. Two thousand five hundred Jews were herded into freight cars. The largest possible number of prisoners was crammed into each car. The train left Iasi on 30 June 194I, between 3.30 and 4. I 5 am. At about 4.00 that same morning, a second group of approximately $\mathrm{I}, 900$ Jews to be evacuated were rounded up at the Chestura. This group consisted of Jews arrested in the days preceding the pogrom and imprisoned in the basement of the Chestura; of the survivors of the butchery in Aleea Alecsandri, who had been held captive at the Gendarmes Headquarters; and of Jews arrested Sunday night or even Monday morning ... The escort of this convoy to the station consisted of gendarmes and police led by Assistant Commissar C. Georgescu and some German soldiers. ${ }^{75}$

Also in the course of Monday morning, 30 June, Sunday's dead and dying were buried together in the Jewish cemetery, in graves that had been dug previously. At $6.00 \mathrm{pm}$ a stonemason called Rotman, an old Jew with a white beard, accompanied by a young man, brought food to the Jews who had been working as grave-diggers

69 Carp, Cartea, 2. 51, testimony of Traian Borcescu. Could the same Florin Becescu-Georgescu be a 'certain Captain Georgescu who commanded a 'Romanian Gestapo' and who together with SS Captain Bart organized the butchery two weeks before it occurred'? Documents, 6. 42. Note that this 'Romanian Gestapo' was seen by witnesses on Pacurari Street, where the first incidents took place. One thing is certain, however: the SSI team headed by Grigore Petrovici confirmed that their leader was present at least once in the Chestura courtyard on Sunday, 29 June. Carp, Cartea, 2. 54-6, testimonies of SSI agents Victor Marinovici, Traian Radulescu and Constantin Petrescu.

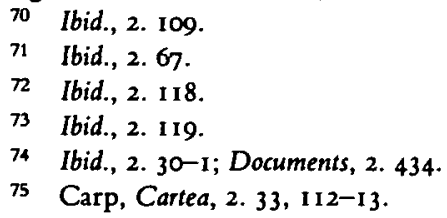


since early morning. Three gendarmes met Rotman and his companion, ordered them to undress and shot them. The old man died instantly. The young man asked to be shot once more. They were buried with the rest. ${ }^{76}$ Not all the corpses in Iasi were buried. German soldiers forced the worker Leizu Blum, of 9 Cucu Street, and a few other men to throw the bodies into the Bahlui River. They also threw in some people 'who were still alive or dying'. 77

It appears that during that Monday, 100 Jews - forced labourers at the tramway power stations - disappeared without trace. ${ }^{78}$ 'On the same Monday morning, the tram conductor Constantin Ifros killed with a crowbar the family of the estate agent Segal: father, mother, and two children, who were walking in the street.' A similar incident had occurred the day before, when a single individual, Gheorghe Condurache, killed six members of the Waisman-Berger family (the tombstone can be seen in the Iasi cemetery) ${ }^{79}$ Again, on the same Monday, a Romanian-German patrol shot the travelling sales representative Lupu Melnik of Codanesti-Vaslui, as well as his wife and son, next to the barracks of the Thirteenth Transmisiuni Regiment at a location known as Manta-Rosie. A thirteen-year-old girl, Etelka Melnik, survived, hidden by a sergeant from the same regiment. ${ }^{80}$

The massacre continued throughout the day [Monday, 30 June I941] at different points in the city. At $1.00 \mathrm{pm}$, for instance, on I. C. Bratianu Street, some armoured car attendants Germans, according to some reports, Romanians according to others - assumed they were attacked with firearms from a building housing a pharmacy. They searched the entire block of flats and seized eighteen Jews - or twenty, according to some reports - including a child with his father and mother. They were taken to Saint Spiridon Square, then at a shop on Vasile Conta Street the prisoners were made to lay face down on the ground and were slaughtered with machine-gun fire from an armoured car. ${ }^{81}$

A photograph was taken of a group of some five or six victims on Vasile Conta Street, among them a four- or five-year-old child. ${ }^{82}$

Jews were forced to efface all traces of the massacre with their bare hands: while rubbish lorries and carts transported the corpses, municipal water carts cleaned the blood in the streets, and newly arrested groups of Jews washed the Chestura courtyard stone by stone to obliterate all traces of blood and sins. ${ }^{83}$

A photograph of this scene has survived. We also have the testimony of the eighty-year-old Leia Moise, of 6 Apeduct Street, whose son and two sons-in-law died in the pogrom:

76 Mircu, Pogromul, 82-3.

77 Ibid., 83.

78 Ibid., 80.

79 Ibid., 80; Carp, Cartea, vol. 2, chart $\mathrm{H}$.

80 Ibid., 2. 97-8, testimony of Richard Filipescu.

81 Ibid., 2. 34, 1 10, 147. The following victims were identified: the owner of a hat store on Stefan cel Mare Street named Kunovici, a baker on I. C. Bratianu Street named Filip Siminovici, the engineer Nacht and the publican Mille.

82 Ibid., 2. I 10.

83 Ibid., 2. 34. 
I went to look for my son, who was attached to civil defence at the electric plant. There were some other people with me, among them a lawyer, Paul Lazar. We were made to clean the courtyard of blood and other remains of the crimes committed. We gathered bits of human brains and we washed blood off stones. We stayed at the Chestura for three days without food. On the third day, an important General came and announced that we were free and explained to us that all that had happened was the fault of the Jews who had fired on the Romanian and German army. ${ }^{84}$

Meanwhile, corpses continued to be robbed and buried. The Italian journalist Curzio Malaparte described how 'detachments of soldiers and gendarmes, groups of working men and women, groups of long-haired Gypsies squabbled, shouting with joy, as they undressed corpses, lifted them up and turned them over' ${ }^{85}$ The carpenter David Itzhac testified that the municipal carts normally used to transport rubbish arrived at the Pacurari cemetery filled with corpses. While some Jews filled the existing graves with bodies, others were digging new ones. 'We worked without interruption for four days and four nights ... during which time my comrades and I buried about 6,000 victims. ${ }^{36}$ Available evidence does not indicate whether there were additional Jewish victims in Iasi during the days that followed, but the Jews deported as a direct consequence of the pogrom continued to die.

\section{The Death Trains}

Two death trains left Iasi. The first one consisted of from 33 to 39 carriages - sealed freight cars containing between 2,430 and 2,530 Jews. ${ }^{87}$ Although 'Colonel Mavrichi, the delegate of Supreme Headquarters to the Iasi railway station, had granted the so cars requested by the lasi county prefect, Colonel Captaru, 12 of them were in reality refused because they were cattle cars with air vents' ${ }^{88}$ In order to crowd 80 to I so Jews into a single carriage, they were hit with rifle butts and bayonets. In the process some were seriously wounded. German soldiers and Romanian police, among them Section Chief Leon Cristiniuc, loaded the train. ${ }^{89}$ Before the train left, planks were nailed over the small air vents, making breathing for the enclosed people most difficult. The freight cars bore the inscription 'Communist Kikes' or 'Murderers of German and Romanian Soldiers' ${ }^{90}$

The first train left Iasi between the hours of 3.30 and 4. I 5 am on Monday, 30 June I94I; its final destination was the town of Calarasi. The train was guarded by a group of public guards led by Sergeant Commander Ion Leucea. ${ }^{91}$ Since some of the orders issued by the Ministry of the Interior, Supreme Headquarters and the county prefecture were contradictory, the route of the train was erratic during the first day.

Documents, 6. 40, testimony of Braunstein.

Curzio Malaparte, Kaputt (Paris: Gallimard, 1972), 167.

Documents, 8. 574 .

87 Carp, Cartea, 2. 31; Mircu, Pogromul, 49; Documents, 2. 448; Karetki and Covaci, Zile, 87, 93.

88 Carp, Cartea, 2. 31 .

89 Documents, 6. 388.

9 Mircu, Pogromul, so; Documents, 6. 404.

91 Carp, Cartea, 2, 3 I. 
At 7.00 am it passed through Tirgu Frumos, located about forty kilometres from Iasi; the distance was covered in approximately three hours at an average speed of twelve kilometres an hour. Without stopping, the train continued towards Pascani and then on to Lespezi, then back to Pascani, and from there to Roman. This is the route described by Matatias Carp and contained in documents in archives of the Ministry of the Interior. But Aurel Karetki and Maria Covaci maintain that the route was Iasi-Roman-Trifesti-Roman. ${ }^{92}$ However, both versions agree that the train arrived in Roman at I I.45 am, where it stopped for almost four hours. That is, the train returned to a spot only forty kilometres from Iasi after a trip of at least seventeen hours.

Throughout the trip the prisoners were forbidden to open the doors for air and were refused water. The heat was unbearable, and in most carriages overcrowding prevented movement. There was mass hysteria. People drank their own urine or the blood flowing from their wounds. Many went mad before dying. ${ }^{93}$ Some prisoners committed suicide. Very many fainted and lost their sense of time. In one carriage eight children and three old people were the only ones left alive by the time the train reached Tirgu Frumos.

The corpses looked strange, frozen in the position in which they had fallen, as if welded together in one mass. The smell in the car was horrible; a mixture of blood, corpses and faeces. It took us a great effort to unglue ourselves from the mass of bodies. ${ }^{94}$

It seems that in the Sabaoani railway station, before reaching Tirgu Frumos, some prisoners ripped wooden planks off carriage walls to get air and managed to escape. Train guards shot at them as well as at those remaining in the car ${ }^{95}$ As soon as the train stopped at Tirgu Frumos, four carriages were opened. These were the last to be filled with the remaining prisoners at Iasi, so they were less crowded than the others. In the first of them, there were " 40 to 50 people, all alive, but confused and in poor physical condition. In the second and third the situation was about the same.... In the third carriage they found one white-bearded old man, dead. 96 About 200 Jews released from these four carriages were escorted to the town synagogue. ${ }^{97}$ Thereafter, a German captain and the Romanian commander of the railway battalion, Danubiu Marinescu, called a halt to the opening of doors and the unloading of prisoners. Several telephone conversations took place between Captain Marinescu, who wanted to execute the prisoners on the train, and the county prefect, who hesitated to unload the corpses as he had no orders to do so from the Ministry of Internal Affairs. ${ }^{98}$

92 Ibid., 2. 31 ; Karetki and Covaci, Zile, 93-4.

93 Documents, 6. 38, testimony of Braunstein. The following went insane: the socialist activist Carol Drimer, the Talmudic scholar Haim Chelber, the merchant Solomon Kahane and the son of the engineer Ghetl Buchman.

94 Carp, Cartea, 2. 92, testimony of Israel Schreier.

95 Ibid., 2. 92; Karetki and Covaci, Zile, 96.

\% Carp, Cartea, 2. 31, 123.

97 Documents, 6. 401.

98 Carp, Cartea, 2. 122, 129, testimonies of Mayor Aurel Totoescu and Dr Constantin Gheorghiu, both from Targu Frumos. 
The 200 people who got off the train (among them two Romanian gentiles, Eugene Bongard and Traian Marcu) were met by Police Commissar Ion Botez. The commissar 'forbade under the penalty of death to give any help to the people on the train'99 and escorted the 200 to the synagogue. 'On the way, as we were thirsty and had not eaten anything since Sunday morning, many of us bent down to drink water from the puddles along the road. Some of us were immediately shot by policeman Botez.' ${ }^{100}$ Another survivor describes similar occurrences: 'Along the way we were beaten by I. Botez. .. I, the undersigned, was pierced by a bayonet by order of Commissar I. Botez'. ${ }^{101}$ While in the synagogue, the Jews were robbed of their fountain pens, jewellery, money and watches. The president of the local Jewish community, Freitag, who came to the synagogue to help those taken off the train, was beaten by the robbers, mostly soldiers. One of the robbers was a schoolteacher, Reserve Lieutenant Dumitru Atudorei. Two of David Bonder's sons refused to hand over a ring and a watch and were shot by an unidentified sergeant, Lieutenant Atudorei's assistant. ${ }^{102}$

On I July I94I, at dawn, a truckload of gendarmes arrived from Iasi at the Tirgu Frumos station, led by Second Lieutenant Aurel Triandaf, who assumed command of the train and ordered that the doors of the cars still sealed be opened and the corpses removed. A survivor provided the following account:

The carriage doors were opened and we heard voices from afar shouting for us to throw the corpses out of the carriage. Those outside could not come near the carriage because of the stench. Those that did draw near had handkerchiefs drawn over their noses.... Local peasants were gathered to look at the Communists who had fired on Romanian and German troops. ${ }^{103}$

The same scene is described by the mayor of Tirgu Frumos as follows:

We tried to get those still alive in the carriages to help us unload the corpses, but this was impossible because the survivors were so weak and because of the foul air from the dead bodies. I ordered the police to bring Gypsies to perform the operation. The Gypsies, tempted by the possibility of finding shoes and clothes, agreed. This action helped save those who were still alive. There were so many corpses. Some carriages were half filled with them, so that it was difficult to complete the unloading within the approximately two hours scheduled... Some carriages contained I 40 to I 45 people, of whom 80 to 90 were dead. ${ }^{104}$

Many of the dead, especially in the first cars 'had broken heads, eyes gouged out, while others had head lesions caused by beatings. Some of them had probably died before they were loaded into the railway carriages at lasi'. ${ }^{105}$ The corpses, 650 or 654, were placed in trucks and carts and transported to the local Jewish cemetery, where they were buried. ${ }^{106}$ After the train had arrived at the station the evening

Documents, 6. 41 .

Carp, Cartea, 2. 135, testimony of Nathan Goldstein.

Ibid., 2. I 34, testimony of Iancu Naftule.

Documents, 6. 402.

Carp, Cartea, 2. 92, testimony of Israel Schreier.

Ibid., 2. I25, testimony of Mayor Aurel Totoescu.

Ibid., 2. 129, testimony of Dr Constantin Gheorghiu.

Documents., 6. 448. 
before, public guard Gheorghe Tanase 'amused' himself by firing his revolver at the windows of the carriages filled with Jews. In the morning he rounded up local Jews, whom he beat up, forcing them to dig graves. During the transportation of corpses from the station to the cemetery, Gheorghe Tanase climbed on top of the bodies in one of the carts and 'threatened the Jews of Tirgu Frumos with the same fate'. ${ }^{107}$

The grave in the cemetery was 20 metres long, 2.5 metres wide and 2.5 metres deep. Paul Teodorescu, a priest from Razboeni, was present at the burial and stood next to some Jewish adolescents who were used as gravediggers when they heard screams from the communal grave filled with bodies. Confronting a German noncommissioned officer who spoke Romanian, the priest insisted that someone was still alive, so he and the Jewish youths paid several Gypsies to dig out the survivor. This occurred between 2.00 and $4.00 \mathrm{pm}$. It was not an easy task; the survivor had been brought early in the morning and was therefore at the bottom of the grave.

At last he was dug out, naked and covered with mud and dirt. A bucket of water was brought to him to wash up. The man who had come back from the dead refused to drink water, but thrust his fists into the bucket and asked for milk to drink. He was given milk and some clothes taken from the dead. He was dressed and placed in an empty truck that had just brought another load of corpses from the railway station. ${ }^{108}$

There was no end to the suffering of those who remained on the train. Prisoners tried to drink the water in swamps along the railway line, dipping strips of cloth torn off shirts. Moreover, while some carriages were opened, others remained sealed. The mayor of Tirgu Frumos tried to give water and bread to the prisoners on the train but was prevented from doing so by Romanian and German soldiers. He was allowed to distribute food after a while, but 'when he wanted to leave the doors open, the prisoners asked us to close them because the soldiers in the train station threw stones at them'. ${ }^{109}$

A derailment delayed the departure of the train from Tirgu Frumos, which stopped for a while at the Ruginoasa platform, where the last corpses were unloaded. Not all the prisoners got to drink water at the Tirgu Frumos station.

We were so thirsty for such a long time, and with water so near, many of us could not hold ourselves back, and escaped through the little window to drink. Most of us were shot at by the soldiers and I myself saw a sergeant (probably Anastase Bratu), an assistant of the train commander Triandaf, execute an eleven-year-old child: as the child jumped out to get a drink of water, the sergeant shot him in the calf of the leg and the child fell. The boy kept begging 'Water! Water!' Then the sergeant grabbed his legs asking 'You want water? Here, drink your fill!' and plunged his head into the Bahlui River, keeping the child's head under water until he drowned, and then let him float down river. ${ }^{110}$

A few days after the burial in Tirgu Frumos, the local rabbi requested permission to spread more earth on the communal grave - because 'fluids had seeped from the corpses' - and to conduct a religious service. Permission was granted. ${ }^{111}$

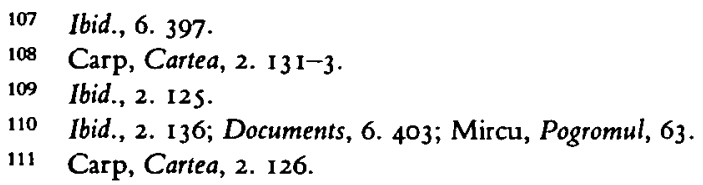


Had the mayor of Tirgu Frumos not attempted, and largely succeeded, in giving water to the prisoners in the railway carriages, and in removing most or all of the corpses, the number of dead would certainly have been greater.

A few days later, the German Consul at Iasi, accompanied by Professor Babinger, a German agent, arrived for an inquest, and enquired what orders had been issued by the Prefect and ascertained that the actions at Tirgu Frumos had been ordered by the Prefect himself. The Prefect was replaced immediately. ${ }^{112}$

On I July between 3.45 and $4.00 \mathrm{pm}$, the death train left Tirgu Frumos for Calarasi under the command of Second Lieutenant of Gendarmes Aurel Triandaf, the non-commissioned officer of gendarmes Anastase Bratu, and thirty gendarmes. It arrived next morning at Mircesti, situated about forty kilometres from Tirgu Frumos. There, 327 corpses were unloaded from the train and buried on the outskirts of Iugani village. ${ }^{113}$ The car doors were opened only to unload the corpses. Numbers of Jews, crazed by thirst, jumped out of the train to drink the water in puddles along the rail line. They were fired upon immediately under orders from Aurel Triandaf, who shot at them himself with his pistol. ${ }^{114}$

On 3 July 194I the train reached Sabaoani, ten kilometres from Mircesti. From there it continued to Roman, some ten kilometres from Sabaoani, where the train was not allowed into the sttaion because of the stench coming from it. By order of Supreme Headquarters, then located at Roman, the train was sent back to Sabaoani, where another 300 corpses were unloaded. ${ }^{115}$ Orders issued by Aurel Triandaf prevented the prisoners from receiving water before the train reached Roman. At many stops the train guards shot at those held in the carriages while at some other stations, German or Romanian soldiers threw stones at them. Railway workers and sometimes soldiers sold pails of water or hats filled with water for exorbitant prices.

From Sabaoani, where the prisoners were examined by Romanian military physicians, the train was again sent on to Roman. In Roman fifty-three corpses were unloaded, and some of the prisoners were bathed and deloused, and left without clothing. The local Romanian Red Cross, headed by Viorica Agarici, extended help to the Jewish prisoners. Next day the Jews were placed in other carriages and the train left Roman, carrying also a load of fifty kilograms of sugar, meant for the use of the prisoners.

On the night of $4 / 5$ July, the train was in Marasesti, about 120 kilometers from Roman. There, ten corpses were unloaded. On the night of $s / 6 \mathrm{July}$, the train stopped at Inosesti, approximately 100 kilometers from Marasesti, where another forty corpses were unloaded. At the next stop, Ploesti, the prisoners received drinking water and 600 loaves of bread. On the afternoon of 6 July, the train reached Calarasi. When it was emptied, there were 1,076 survivors, 69 of whom were dying, and 25 corpses. At this point the mission of the escorting gendarmes

112 Ibid.

113 Ibid., 2. 35.

114 Ibid.; Documents, 6. 405.

115 Carp, Cartea, 2. 36, 137. 
was completed. On their return to Bucharest, they each received half a loaf of bread, cheese, two glasses of wine and about 70 lei. ${ }^{116}$

In summation, the first death train, which left Iasi early in the morning on 30 June with 2,530 Jews, reached Calarasi on the afternoon of 6 July with I, o I I survivors (more died in the following days). A stretch of approximately 500 kilometres was covered in six and one half days, during the heat of summer, mostly without water. The number of corpses taken off the train included 654 at Tirgu Frumos, 327 at Mircesti, 300 at Sabaoani, 53 at Roman, 40 at Inotesti and 25 at Calarasi. It should be noted that as soon as corpses began to be unloaded, and especially after the prisoners were permitted to receive water, the number of the dead decreased dramatically.

Over I,400 Jews had been murdered on the first death train. The survivors were interned in Calarasi, in the courtyard of the twenty-third Infantry Regiment, where they were detained for two months, until 30 August 194I. An improvement in the detaines' living conditions was made possible in this camp through bribery and corruption. Also, a delegate of the Bucharest Jewish community was permitted to assist the internees. The majority were detained in the regimental parade ground; Ioo children and Ioo intellectuals were moved to synagogues in the city. In the first days, about two-thirds of the prisoners were left completely naked. During their detention at the Calarasi camp, 99 prisoners died, including the 69 who were dying as they were taken off the train. Almost 100 sick people were hospitalised locally. Some prisoners were sent to forced labour in Georgeni and Pia Petrea. ${ }^{117}$ At the end of August I94I, it was decided to free the Jews from the Calarasi camp and send them home. They were entrusted to a Romanian military escort who defended them throughout the trip to Iasi from hooligans gathered at various train stations. ${ }^{118} \mathrm{We}$ do not know the name of the lieutenant who, according to many witnesses, protected the former detainees and treated them in an exemplary manner.

The history of the second death train is shorter but equally horrifying. On 30 June I94I, at about $6.00 \mathrm{am}, \mathrm{I}, 902$ Jews were loaded onto a second train comprising eighteen carriages, the last of which contained eighty corpses picked up at the Iasi station - people who had been shot, stabbed with bayonets or crushed with hammers used for railway maintenance. The train took eight hours to cover the twenty kilometres between Iasi and Podul Iloaei. At times the train moved so slowly that the escort followed it on foot. Crowding, despair, heat and thirst caused death. Upon arrival some carriages contained roo dead and three or four almostdead survivors. In some carriages, one person had died every two or three minutes.

Dr Peretz, observing that his father and two brothers were about to die, squeezed through a hole in the carriage floor in search of water. He was shot by a German soldier. A short while later, his father and one of his brothers died; the other brother survived. Tili Smilovici offered a soldier 100,00o lei for a glass of water. The soldier disappeared, and Smilovici jumped out of the car to drink from a puddle. He was

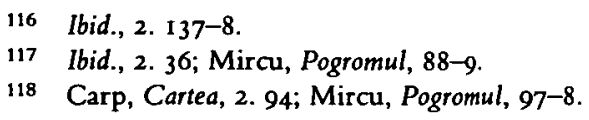


shot. The dentist Friedman, a bridegroom of three days, bought a glass of water for 20,000 lei. He was given a glass of sodium hydroxide, which he drank. He died shortly afterward. Another dentist, Goldman, repeatedly tried to commit suicide but was stopped by other detainees. ${ }^{119}$

Of the 1,902 Jews put on the train, I, 194 died and were buried in the Podul Iloaei cemetery. Some survivors drank water from a marsh where pigs bathed and died, or fainted and drowned. The survivors were first locked in the Podul Iloaei synagogue, then placed in Jewish homes in the village. They were allowed to return to Iasi after four to five weeks; there were thirty-nine women among them. ${ }^{120}$ The names of the escorts in charge of the Iasi-Podul-Iloaei train are not known. The leader may have been a captain in command of Romanian soldiers. It seems that on this train some of the prisoners themselves robbed the dead and dying of watches and jewellery. According to some witnesses from Podul Iloaei, the president of the local Jewish community appropriated jewellery and valuables found on the corpses. ${ }^{121}$

\section{Responsibility for the Pogrom}

The number of victims of the Iasi pogrom cannot be established with certainty. While the number of victims on the trains is known and relatively accurate, we do not know how many Jews in Iasi were buried in communal graves, how many such graves there were, and how many corpses were simply thrown on rubbish heaps or in the Bahlui River. German diplomats in Bucharest estimated at least 4,000 victims, and Raul Hilberg accepted this figure. Curzio Malaparte mentioned 7,000 victims. The most reliable source seems to be documents from the archives of the Ministry of the Interior which, according to Gheorghe Zaharia, place the number of dead at over 8,000 victims. ${ }^{122}$ These documents were used at the Antonescu trial, where the indictment mentioned 10,000 victims of the Iasi pogrom. Other sources, such as Matatias Carp, Pinhas Hakehilot, the linguist Iorgu Iordan and the newspaper Scienteia (1945), all speak of 12,000 victims. 'It is relatively clear who was responsible for the collective murders at Iasi. The murders bear the distinct characteristics of a pogrom rather than the cold, systematic efficiency of the final solution as implemented by Germans and Hungarians.' ${ }^{123}$

This distinction needs to be underscored, especially in the light of attempts rather clumsy at that - by some Romanian historians, such as Aurel Karetki, Maria Covaci and Nicolae Minei, to attribute the overwhelming responsibility for the Iasi pogrom to the German military authorities. German complicity and sometimes initiative are evident, as in the Chestura courtyard or during the freight-car embarkations at the lasi railway station. But it is also evident that the German troops who

119 Carp, Cartea, 2. 33; Documents, 6. 39.

120 Carp, Cartea, 2. 33; Documents, 6. 406-7; Mircu, Pogromul, 76-9.

121 Documents, 6. 52.

122 Gheorghe Zaharia, Pages de la resistance antifasciste en Roumanie (Bucharest: Meridiane, 1974), 45.

123 Nicholas Nagy Talavera, The Green Shirts and the Others (Stanford: Hoover Institution Press, 1970), $331-2$. 
took action against Jews at Iasi behaved generally in an unorganised, chaotic manner. This characterisation applies equally to the Romanian soldiers participating in the pogrom. On the other hand, the Romanian gendarmes and police units acted on clear orders to search homes and arrest suspects.

The fact is that what happened at Iasi was a pogrom of huge proportions. Ion Antonescu, at a meeting of the Council of Ministers on S April I94I, made a most revealing statement regarding the liquidation of Jews, which matched precisely what happened at Iasi: 'I let the mob loose to massacre them. I withdraw to my citadel, and after the massacre, I restore order.' 124

Documents consulted to date appear to prove that the pogrom was organised by the SSI leadership in close collaboration with Section II of Supreme Headquarters. These two organisations conceived the pogrom as one in a series of operations against the internal enemy, 'Judeo-Bolshevism'. The joint co-ordination of the pogrom is clear because SSI officers, in uniform or under cover, carried identity cards issued by Supreme Headquarters. It is also clear that Lieutenant-Colonel Ionescu-Micandru, head of the German section of the SSI, was implicated in the organisation of the pogrom and that he was connected with Major Alexander Hermann von Stransky of the Abwehr. The involvement of SSI agents Gheorghe Balotescu, Emil Tulbure, Grigore Petrovici and Gica Cristescu in the pogrom is also evident. The part that von Stransky played in the organisation of the pogrom is not entirely understood. Was he the liaison between the Romanian and the German military authorities during the pogrom? If so, who gave him his orders? Was he merely an Abwehr agent, or did he also work for other German secret services? Von Stransky did not have decision-making powers in the SSI organisation, but, because of his connections with the SSI leadership, he probably could influence decisions.

It is certain that the SSI armed the Iron Guards who instigated and took part in the pogrom. This raises the question whether Eugen Cristescu, head of SSI, could have armed the Iron Guards, enemy of the regime, without approval from higher authority. It is unlikely that Cristescu risked his position by acting without authorisation. According to later testimony given by SSI officers, Eugen Cristescu kept both Mihai Antonescu and Ion Antonescu informed about the progress of the Iasi massacres. According to the same witnesses, SSI Operative Echelon I sent Mihai Antonescu an album of photographs of the Iasi pogrom, justifying it with the false story that Soviet partisans started the operation when they opened fire on Romanian and German troops. ${ }^{125}$

German soldiers did act against the Jewish population of Iasi. They came from a variety of German units: the SS, the Wehrmacht, under the command of General von Salmuth, and the Todt organisation. They opened fire at random in the streets, murdered Jews in the Chestura, beat and mutilated Jews, escorted Jews to the railway station and loaded trains. In most cases they acted jointly with Romanian soldiers, policemen or gendarmes. If the German soldiers had been given orders

125 Carp, Cartea, 2. so; Documents, 6. 378. 
systematically to exterminate the Iasi Jewish population, they would not have permitted the two trains to leave the city.

The communiqué regarding the execution of ' 500 Judeo-Bolshevik agents' issued in Bucharest was written after the Chestura massacre in order to justify it and also to serve as a means of anti-semitic propaganda. However, it is now clear that there was an explicit order from Ion Antonescu and the Supreme Headquarters (Field HQS) to execute the Jews in Iasi. On 29 June 194I General Ioanitiu, the chief of the General Headquarters (Marele Cartier General) of the Romanian army, issued an order which indicated that the Jewish population worked with the enemy agents behind the front line against the Romanian army and, quoting General Antonescu, asked for severe measures of retaliation. ${ }^{126}$ The next day General Ioanitiu issued the following order: 'Patria towards Bucur. General Antonescu ordered that all the Jewish communists from Iasi and those who were found with red flags and firearms to be executed tonight. Report the execution [of the order] to Ialomita. General Ioanitiu. No. 209 from 30 VI 94 I. '127 The order from the Ministry of the Interior to 'clear the land' was issued during the same day. Many Romanian documents attest to the chaos, improvisation and disorder that ruled during the arrest of the Jews at Iasi.

Apart from the SSI, which unleashed the pogrom at Iasi, the responsibility for its execution rested largely with the local military authorities. Among these was Colonel Constantin Lupu, commander of the Iasi garrison. He did not attempt to arrest the armed Iron Guards, and the troops under his command participated in plunder, arrests and the murder of Jews. Colonel Dumitru Captaru, the county prefect, received and executed the order to evacuate the Iasi Jews by train. He requested and received the necessary evacuation orders from the Ministry of the Interior and from Mihai Antonescu, substituting for Ion Antonescu, who was then at the front. Although Lieutenant-Colonel Constantin Chirilovici, the Chestor of Iasi, did act to prevent some murders, he also participated indirectly, through the police force under his command, in the arrest and abuse of Jews. In reports to his superiors, his deep-rooted and violent anti-Jewish hatred is clear. Finally, General Stavrescu, commander of the Fourteenth Division, participated in all the decisions regarding the arrest and evacuation of Jews.

It is interesting to note that in documents signed by high-ranking Romanian officers implicated in the lasi pogrom there is a great difference in tone and attitude towards Jews during and after the war. In the course of the pogrom and immediately afterwards, Jews were described as 'representatives of internal forces siding with Communism in our country, seeking our country's destruction ... the only minority that protects and shelters Soviet paratroopers and terrorists'. ${ }^{128}$ After the war, in depositions from the same officers, Jews are realistically described as victims. It is also interesting to note that when the trials of war criminals started, the various

126 United States Holocaust Memorial Museum Archives/Marele Stat Major Archives, reel 305 , fond Marele Cartier General, folder 3828, document 32.

127 Ibid., document 56.

128 Documents, 3. 67. 
Romanian military branches tended increasingly to shift responsibility for the massacre of Jews to German officers or other Romanians, thereby contributing to the argument that the Germans were exclusively responsible for the massacre.

To summarise, the Iasi pogrom was certainly instigated by high-ranking elements of the SSI with possible German co-operation (von Stransky). These elements used as tools, as 'detonators', members of the illegal Iron Guard who succeeded to a certain degree in getting the support of a fraction of the local population. The main instruments through which the pogrom was carried out were, on the Romanian side, Romanian army and gendarmerie units moving towards the front line, the local Romanian administration and police. On the German side, SS troops, soldiers belonging to the Todt organisation, participated in the killings. The Germans together with the Romanians killed randomly in the streets of Iasi and in the yard of the Prefecture and escorted the columns of the Jews to the railway station. No Einsatzengruppe type of execution took place in Iasi, and the Germans were not involved at all in the transport of Jews.

If there is no clear proof that the lasi pogrom was ordered by the highest Romanian officials it is clear that, once the pogrom started, Ion Antonescu ordered the executions and Mihai Antonescu encouraged the deportations. Meanwhile both Ion Antonescu and Mihai Antonescu showed during the summer of 1941 a strong determination to 'clean' Bessarabia and Bukovina of the Jews without mercy and by any means. The mass killings from Bessarabia, Bukovina and Transnistria, and the deportation of the survivors to Transnistria, are tragic illustrations of this strong will. The analysis of the pogrom of Iasi should take in account the relative lack of capacity for organisation which was shown during the war by the Romanian military administration. A few weeks later German protests were sent to highranking Romanian officials emphasising the disorderly way in which the Romanians were killing Jews. The events from the city of Iasi show a certain lack of co-ordination. Between killings, Jews were arrested, released and arrested again. Thousands were deported, thousands not. Also, there was a certain hesitation concerning the final destination of the death trains.

At the end of the autumn of 194I there were only 20,000 Jews in Bukovina in the ghetto of Cernauti, a few hundred in Bessarabia and about 150,000 Romanian Jewish deportees in Transnistria from which only 50,000 survived. Over 100,000 local Jews from Transnistria were later exterminated under Romanian administration.

\section{The Aftermath}

The Romanian war criminals implicated in the Iasi pogrom were sentenced on 26 June 1948 after a trial in Bucharest. ${ }^{129}$ The following were sentenced to forced labour for life and the loss of civil rights for ten years: General Gheorghe Stavrescu, former commander of the Fourteenth Division; Colonel Dumitru Captaru, former 
prefect of Iasi County; Lieutenant-Colonel Constantin Ionescu-Micandru, former chief of the German section of the SSI; Majors Gheorge Balotescu and Emil Tulbure and Inspectors Gheorghe Cristescu and Grigore Petrovici, all SSI officers and members of SSI Operative Echelon I; Lieutenant-Colonel Danubiu Marinescu, who prevented the unloading of prisoners from the death train at Tirgu Frumos and withheld permission to give them water; Second Lieutenant Aurel Triandaf, the officer in charge of the train from Tirgu Frumos to Calarasi; Sergeant Mircea Manoliu, who had murdered several people at the outbreak of the pogrom; the policemen Dumitru Cercel and Gheorghe Grosu; and the civilians Gheorghe Condurache, Dumitru Dumitriu, Emile Visovschi, Ghita Iosub, Rudolf Lubas and Dumitru Rusu.

In addition, Colonel Constantin Lupu, former commander of the Iasi garrison, was sentenced to life imprisonment, ordered to pay a fine of 100 million lei, and stripped of his rights of citizenship for ten years. The public guards Leon Cristiniuc, Gheorghe Bocancea and Mihai Anitulesei, as well as the civilians Dumitru Andronic, Constantin Blindut, Ion Laur and Stefan Scobai, were sentenced to twenty-five years' forced labour, fines of 100 million lei and loss of citizenship for ten years..

The following received sentences of twenty years' hard labour, fines of 100 million lei and the loss of civil rights for ten years: public guards Dumitru Ciubotaru, Gheorghe Tanase and Ion Manastireanu; policeman Alexandru Pasarica; the soldier Florian Ciornei; and civilians Constantin Lazar, Dumitru Moraru, Gheorghe Parlafes, Vasile Velescu and Diumitru Constantinescu.

Second Lieutenant Dumitru Atudorei, who robbed and murdered Jews in Tirgu Frumos, Aurel Gramatiuc, who was a high school student at the time of the pogrom, and the civilians Nicolae Miron and Nicolae Rusu received fifteen years' hard labour, fines of Ioo million lei and the loss of civil rights for ten years. The civilian Ion Ciobanu, also known as Balteanu, was sentenced to five years' hard labour, was fined Ioo million lei and lost his civil rights for ten years.

The policemen Dumitru Chicicov and Ion Leucea and former Iron Guard Gheorghe Andreias were found not guilty.

Thus, at the trial of those implicated in the Iasi pogrom, 46 persons were found guilty. Of these, it were army officers, io were policemen and one was an enlisted man. Twenty-two persons in military uniform therefore participated in the events at Iasi. Of those found guilty, 46 per cent were members of the Romanian army or police. The others were civilians, some of them former members of the Iron Guard or of the Government Railways. With one exception, no gendarmes or simple soldiers guilty of homicide or brutality at Iasi were brought to justice; nor were the escorts of the death trains, with one exception, brought to trial. Eugen Cristescu, former head of SSI, did not face the court for the Iasi pogrom; he had already been sentenced in an earlier trial. No German enlisted men or officers implicated in the pogrom ever came to trial. In an address to parliament on 29 June 1947, Dumitru Pop, Socialist-Democrat representative, 
concluded: 'Not only Jews were murdered at Iasi, morality was murdered, the country's good name was murdered.'130

The destruction of Romanian Jewry was systematic in Bessarabia, Northern Bukovina and Transnistria in I94I and 1942. All the Jews from Bessarabia and almost all the Jews from Northern Bukovina (except 20,000 Jews from the Czernowitz ghetto) were either killed or deported to Transnistria. Tens of thousands of Jews were massacred by the Romanians and the Germans in Bessarabia and Bukovina during the summer of I94I. At least I 8,000 Romanian Jews were deported to Transnistria, from which 50,000 survived. Over 100,000 local Jews were killed under the Romanian administration in Transnistria. All these genocidal measures were approved by Ion Antonescu and carried out through the orders of the General Staff of the Romanian Army and through the Ministry of the Interior. In 1942, despite strong German pressures, Antonescu decided to postpone the deportation of the Romanian Jews to Belzec due to intervention from abroad, through the Swiss and Vatican legations and from inside Romania (the leaders of the Jewish community, the Royal House and Archbishop Balan of Transylvania). In I943 Romanian Jewry began to become a bargaining chip for the Romanian authorities who realised that the Germans would lose the war. In I944 thousands of deportees from Transnistria were allowed to return to Romania and to emigrate to Palestine. Meanwhile, in Northern Transylvania, Hungarians and Germans deported to Poland almost all of the I 50,000 Jews, of which only i 5,000 returned after the war. The main features of the Holocaust in Romania were defamation, outbursts of violence, disorder, robbery, selective extermination on a geographical basis and opportunism. These policies were put into practice extensively and rapidly at the beginning of the war and ended slowly in 1943; most of the time there was no co-ordination between Romanian and German policies in this matter. The pogrom of Iasi resembles the pogroms of Lvov or Kovno where the local population was encouraged to kill Jews. However, Iasi was under Romanian administration and not under German occupation. The pogrom of Iasi represents the beginnings of the genocidal process implemented by the Romanian authorities through which at least 200,000 Romanian Jews and over 100,000 Ukrainian Jews were killed.

Romania is not yet ready to cope with its past. Fifty years after the pogrom of Iasi, during its commemoration, a violent anti-semitic campaign unfolded. Most of the Romanian press denied the existence of the Holocaust in Romania, blaming the Germans or the Hungarians for the killings. The attitude of the Romanian authorities was characteristic: lip service was paid to the victims, but meanwhile Romanian responsibility was ignored. In May I99I the members of the Romanian Parliament stood up in a moment of silence for Ion Antonescu.

Translated by Mara Vamos Soceanu 